\title{
Weed Dynamics and Productivity of Hybrid Maize (Zea mays) as Affected by Integrated Weed Management Practices
}

\author{
R. Nagasai Vardhan Naik $^{1 *}$ and A. Velayutham ${ }^{2}$ \\ ${ }^{1}$ Department of Agronomy, Agricultural College and Research Institute (AC\&RI), \\ Killikulam, India \\ ${ }^{2}$ Department of Farm Management, AC\&RI, Killikulam, Tamil Nadu, India \\ *Corresponding author
}

\begin{abstract}
A B S T R A C T
A field experiment was conducted during Rabi season of 2015-2016 at Agricultural College and Research Institute, Killikulam to find out the most effective weed control

\section{Keywords}

Economics, Herbicides,

Integrated weed

management, Maize,

yield

Article Info

Accepted:

24 February 2018

Available Online:

10 March 2018 measure study weed dynamics, productivity and economics of hybrid maize as affected by integrated weed management. None of the pre-emergence herbicides alone provided desired control of weeds. However, inclusion of one hand weeding at 30 DAS with preemergence herbicides markedly improved weed control efficiency (WCE), yield attributes, grain and stover yield. Alachlor @ $1.5 \mathrm{~kg}$ a.i./ ha + HW at 30 DAS proved most effective in controlling weeds (WCE 90.33\%) followed by two hand weedings at 15 and 30 DAS(WCE $84.08 \%$ ) and they reduce the weed density and weed biomass significantly, which in turn increased yield compared with unweeded control. Significantly highest grain yield were recorded underalachlor @ $1.5 \mathrm{~kg}$ a.i./ ha $+\mathrm{HW}$ at 30 DAS $\left(7115 \mathrm{~kg} \mathrm{ha}^{-1}\right)$ followed by two hand weedings at 15 and 30 DAS $\left(6855 \mathrm{~kg} \mathrm{ha}^{-1}\right)$ and mechanical weeding with power weeder twice on 15 and $30 \mathrm{DAS}\left(6714 \mathrm{~kg} \mathrm{ha}^{-1}\right)$. The highest net returns and highest benefit: cost ratio were obtained under alachlor @ $1.5 \mathrm{~kg}$ a.i./ ha + HW at 30 DAS followed by two hand weedings at 15 and 30 DAS.
\end{abstract}

\section{Introduction}

Maize (Zea mays L.) is an important cereal crop of India. The grains of maize are used in a variety of ways by the human beings. Recently, with the release of improved cultivars and hybrids, the grain yield has been increased but still the maize crop faces many problems. Farmers usually give prime importance to few cultural practices and neglect other factors like seed rate and weed control. Maize crop gets infested with variety of weeds and subjected to heavy weed competition, which often inflicts huge losses ranging from 28 to $100 \%$ (Patel et al., 2006). Weed management strategies attempt to limit the deleterious effects of weeds growing with crop plants. These effects could be quite variable, but the most common is competition for available resources. The quantities of growth factors used by weeds are thus unavailable to the crop. The extent of nutrient loss varies from 30-40 \% of the applied nutrients (Mundra et al., 2002). Hence, 
suitable weed control strategies in maize can be the sequential use of pre-emergence and post-emergence herbicides or a pre-emergence herbicide application followed by two hand weedings or intercultural operation with power weeder so that the crop is protected well against the weeds during the critical period of crop weed competition. Atrazine, alachlor and pendimethalin are widely used for control of weeds in maize. But their continuous use for long time may lead development of herbicide resistance in weeds (Pandey et al., 2000). Hence, there is a need to develop integrated weed management strategies for effective weed control and to realize higher maize productivity.

\section{Materials and Methods}

The field experiment was conducted duringRabi season of 2015-2016 at Department of farm management, Agricultural College farm, Agricultural College and Research Institute, Killikulam. The experimental field is geographically located in the southern part of Tamil Nadu at $8^{\circ} 46^{\prime}$ North latitude and $77^{\circ} 42^{\prime}$ East longitude at an altitude of 40 meters above mean sea level. The experimental site was sandy clay loam, $0.34 \%$ organic carbon, neutral in reaction $(\mathrm{pH}$ 7.28), low in available $\mathrm{N}\left(198 \mathrm{~kg} \mathrm{ha}^{-1}\right)$, low in available $\mathrm{P}\left(10.1 \mathrm{~kg} \mathrm{ha}^{-1}\right)$ and medium in available $\mathrm{K}\left(139 \mathrm{~kg} \mathrm{ha}^{-1}\right)$.

The experiment was laid out in a randomized block design with three replications. The gross plot size was $5 \times 3.6 \mathrm{~m}$ and net plot size was $4.5 \times 3.1 \mathrm{~m}$. A set of nine twelve treatments comprising $\mathrm{T}_{1}$ - Alachlor @ $1.5 \mathrm{~kg}$ a.i ha ${ }^{-1}, \mathrm{~T}_{2}$ Alachlor@1.5 kg a.i ha ${ }^{-1}+$ one hand weeding on 30 DAS, T 3 - Alachlor @ $1.5 \mathrm{~kg} \mathrm{a.i} \mathrm{ha}{ }^{-1}+$ one mechanical weeding with power weeder on 30 DAS, T T $_{4}$ Atrazine @ $0.25 \mathrm{~kg}$ a.i ha ${ }^{-1}$, $\mathrm{T}_{5}$ - Atrazine@0.25 kg a.i ha ${ }^{-1}+$ one hand weeding on 30 DAS, T 6 - Atrazine @ $0.25 \mathrm{~kg}$ a.i ha ${ }^{-1}+$ one mechanical weeding with power weeder on 30 DAS ; $\mathrm{T}_{7}$ - Pendimethalin@ $0.75 \mathrm{~kg}$ a.i ha ${ }^{-1}, \mathrm{~T}_{8}$ - Pendimethalin @ $0.75 \mathrm{~kg}$ a.i ha ${ }^{-1}+$ one hand weeding on $30 \mathrm{DAS}, \mathrm{T}_{9}-$ Pendimethalin@0.75 kg a.i ha ${ }^{-1}+$ one mechanical weeding with power weeder on 30 DAS, $T_{10}$ - Hand weeding twice on 15 and 30 DAS, $T_{11}$-Mechanical weeding with power weeder twice on 15 and $30 \mathrm{DAS}, \mathrm{T}_{12}$ Unweeded control. Maize hybrid COH (M) 6 sown with a spacing of $60 \times 25 \mathrm{~cm}$. Crop was fertilized with 250:75:75 Kg NPK ha ${ }^{-1}$ through urea, single super phosphate and muriate of potash respectively.

Thinning was done at 15 DAS to maintain plant to plant distance of $25 \mathrm{~cm}$. Thinning was done at 10 DAS to maintain plant to plant distance of $25 \mathrm{~cm}$. All the herbicides dissolved in water $\left(500 \mathrm{~L} \mathrm{ha}^{-1}\right)$ were sprayed as preemergence on the next day of sowing.

\section{Results and Discussion}

\section{Weed flora}

The predominant weed species observed in the experimental field were Cyperus rotundus among sedges, Cynodon dactylon among grasses and Digeraarvensis, Trianthema portulacastrum, Cleome viscosa and Phyllanthus niruri among broad-leaved weeds. Among all the three weed groups, the most predominant weed species observed was Cyperus rotundus.

\section{Plant height, leaf area index and dry matter production}

Highest plant height, leaf area index and dry matter production was noticed with alachlor @ $1.5 \mathrm{~kg}$ a.i ha ${ }^{-1}$ with one hand weeding on 30 DAS $\left(T_{2}\right)$ which was however, on par with hand weeding twice on 15 and 30 DAS $\left(\mathrm{T}_{10}\right)$ (Table 1). This might be due to lesser weed infestation as evident from lower weed dry matter. 
Table.1 Growth and yieldof hybrid maize as influenced by different weed management practices

\begin{tabular}{|c|c|c|c|c|c|}
\hline Treatments & $\begin{array}{l}\text { Plant } \\
\text { height } \\
(\mathrm{cm}) \text { at } \\
\text { harvest }\end{array}$ & $\begin{array}{c}\text { LAI } \\
(60 \\
\text { DAS })\end{array}$ & $\begin{array}{c}\text { Dry matter } \\
\text { production } \\
\left(\mathrm{kg} \mathrm{ha}^{-1}\right) \text { at } \\
\text { harvest }\end{array}$ & $\begin{array}{l}\text { Crop Growth } \\
\text { Rate }\left(k^{-1} \text { ha }^{-1}\right. \\
\left.\text { day }^{-1}\right)(30-60 \\
\text { DAS })\end{array}$ & $\begin{array}{c}\text { Grain } \\
\text { yield (kg } \\
\text { ha }^{-1} \text { ) }\end{array}$ \\
\hline T1 - Alachlor@1.5 kg a.i ha ${ }^{-1}(\mathrm{PE})$ & 221.0 & 4.03 & 15970 & 212.7 & 6431 \\
\hline T & 244.6 & 4.46 & 17660 & 235.2 & 7115 \\
\hline $\begin{array}{l}\mathrm{T}_{3} \text {-Alachlor @ } 1.5 \mathrm{~kg} \text { a.i ha }{ }^{-1}+\text { one mechanical weeding with power } \\
\text { weeder on } 30 \text { DAS }\end{array}$ & 226.7 & 4.13 & 16350 & 217.7 & 6584 \\
\hline T 4 - Atrazine@0.25 kg a.i ha ${ }^{-1}(\mathrm{PE})$ & 205.1 & 3.74 & 14780 & 196.7 & 5959 \\
\hline $\mathrm{T}_{5}$ - Atrazine @ $0.25 \mathrm{~kg}$ a.i ha ${ }^{-1}+$ one hand weeding on $30 \mathrm{DAS}$ & 228.4 & 3.90 & 15430 & 207.7 & 6218 \\
\hline $\begin{array}{l}\mathrm{T}_{6} \text { - Atrazine @ } 0.25 \mathrm{~kg} \text { a.i ha }{ }^{-1}+\text { one mechanical weeding with power } \\
\text { weeder on } 30 \mathrm{DAS}\end{array}$ & 208.2 & 3.80 & 15040 & 200.3 & 6053 \\
\hline T - Pendimethalin @ 0.75 kg a.i ha ${ }^{-1}(\mathrm{PE})$ & 208.6 & 3.50 & 13870 & 184.0 & 5581 \\
\hline T 8 - Pendimethalin@ $0.75 \mathrm{~kg}$ a.i ha ${ }^{-1}+$ one hand weeding on 30 DAS & 199.5 & 3.63 & 14380 & 191.2 & 5793 \\
\hline $\begin{array}{l}\mathrm{T}_{9} \text { - Pendimethalin @ } 0.75 \mathrm{~kg} \text { a.i ha }{ }^{-1}+\text { one mechanical weeding with } \\
\text { power weeder on } 30 \text { DAS }\end{array}$ & 196.4 & 3.58 & 14170 & 189.2 & 5711 \\
\hline $\mathrm{T}_{10}$ - Hand weeding twice on 15 and 30 DAS & 235.7 & 4.30 & 17020 & 226.2 & 6855 \\
\hline $\begin{array}{l}T_{11} \text { - Mechanical weeding with power weeder twice on } 15 \text { and } 30 \text { DAS } \\
T_{12} \text { - Un weeded control }\end{array}$ & $\begin{array}{l}231.0 \\
170.7\end{array}$ & $\begin{array}{c}4.21 \\
3.12\end{array}$ & $\begin{array}{l}16660 \\
12340\end{array}$ & $\begin{array}{c}221.7 \\
164\end{array}$ & $\begin{array}{l}6714 \\
4967\end{array}$ \\
\hline SEd & 5.5 & 0.39 & 402 & 5.4 & 162 \\
\hline $\mathrm{CD}(\mathrm{p}=0.05)$ & 11.5 & 0.81 & 832 & 11.1 & 335 \\
\hline
\end{tabular}


Table.2 Weed dynamics and weed control efficiency of hybrid maize as influenced by different weed management practices

\begin{tabular}{|c|c|c|c|}
\hline Treatments & $\begin{array}{l}\text { Weed } \\
\text { density } \\
\left(\text { No. } \text { m }^{-2}\right)\end{array}$ & $\begin{array}{l}\text { Weed dry } \\
\text { matter (kg } \\
\left.\text { ha }^{-1}\right)\end{array}$ & $\begin{array}{l}* \text { Weed control } \\
\text { efficiency }(\%)\end{array}$ \\
\hline T1 - Alachlor@ 1.5 kg a.i ha ${ }^{-1}(\mathrm{PE})$ & $\begin{array}{l}42.61 \\
(6.57)\end{array}$ & 475.1 & 80.48 \\
\hline T & $(5.65)$ & 186.0 & 90.33 \\
\hline $\begin{array}{l}\mathrm{T}_{3} \text { - Alachlor @ } 1.5 \mathrm{~kg} \mathrm{a.i} \mathrm{ha}{ }^{-1}+\text { one mechanical weeding with power weeder } \\
\text { on } 30 \text { DAS }\end{array}$ & $\begin{array}{l}27.24 \\
(5.27)\end{array}$ & 447.3 & 82.79 \\
\hline T 4 - Atrazine@0.25 kg a.i ha ${ }^{-1}(\mathrm{PE})$ & $\begin{array}{l}46.58 \\
(6.86)\end{array}$ & 681.4 & 69.65 \\
\hline T5 - Atrazine @ 0.25 kg a.i ha ${ }^{-1}+$ one hand weeding on 30 DAS & $\begin{array}{l}24.41 \\
(4.99)\end{array}$ & 583.6 & 73.71 \\
\hline $\begin{array}{l}\mathrm{T}_{6} \text {-Atrazine@ } 0.25 \mathrm{~kg} \text { a.i ha }{ }^{-1}+\text { one mechanical weeding with power weeder } \\
\text { on } 30 \text { DAS }\end{array}$ & $\begin{array}{l}28.97 \\
(5.43)\end{array}$ & 647.2 & 71.69 \\
\hline $\mathrm{T}_{7}$ - Pendimethalin @0.75 kg a.i ha ${ }^{-1}(\mathrm{PE})$ & $\begin{array}{l}49.64 \\
(7.08)\end{array}$ & 862.4 & 64.89 \\
\hline T8 - Pendimethalin@ 0.75 kg a.i ha ${ }^{-1}+$ one hand weeding on 30 DAS & $\begin{array}{l}24.78 \\
(5.03)\end{array}$ & 780.3 & 66.34 \\
\hline $\begin{array}{l}\text { T9 - Pendimethalin @ } 0.75 \mathrm{~kg} \mathrm{a.i} \mathrm{ha}^{-1}+\text { one mechanical weeding with power } \\
\text { weeder on } 30 \text { DAS }\end{array}$ & 28.54 & 836.6 & 63.55 \\
\hline $\mathrm{T}_{10}$ - Hand weeding twice on 15 and $30 \mathrm{DAS}$ & $\begin{array}{l}20.87 \\
(4.62)\end{array}$ & 394.6 & 84.08 \\
\hline $\begin{array}{l}T_{11} \text { - Mechanical weeding with power weeder twice on } 15 \text { and } 30 \text { DAS } \\
T_{12} \text { - Un weeded control }\end{array}$ & $\begin{array}{c}44.36 \\
(6.70) \\
134.35 \\
(11.61)\end{array}$ & $\begin{array}{l}418.2 \\
1756.2\end{array}$ & 83.59 \\
\hline SEd & 0.34 & 1.05 & - \\
\hline $\mathrm{CD}(\mathrm{p}=0.05)$ & 0.70 & 2.19 & - \\
\hline
\end{tabular}

*Data not statistically analysed 
The LAI (leaf area index) and CGR (crop growth rate) increased upto 90 DAS and declined there after marginally due to senescence. Alachlor @ $1.5 \mathrm{~kg}$ a.i ha ${ }^{-1}$ with one hand weeding on 30 DAS $\left(\mathrm{T}_{2}\right)$ created weed free environment, reduce weed density and biomass, which would have favoured the crop to grow well, producing more photosynthetic area, which ultimately lead to higher LAI and CGR. Better stature of crop, as reflected by taller plants, higher LAI and CGR would have enhanced the photosynthesis, which in turn resulted in higher dry matter production (Table 1).

\section{Grain yield}

The highest grain yield was recorded with alachlor@1.5 kg a.i ha ${ }^{-1}$ as pre-emergence with one hand weeding on 30 DAS (Table 1), which was in parity with hand weeding twice on 15 and 30 DAS. This was due to lesser crop weed competition for growth resources throughout the crop growth period and availability of congenial environment for better expression of growth and yield potential. Similar findings were reported by Pandey et al., (2001), Sunitha et al., (2011) and Sandhya Rani and Karuna Sagar (2013). Heavy weed infestation in control $\left(\mathrm{T}_{12}\right)$ had deprived the crop for all the growth resources and resulted in poor performance of corn (Table 1).

\section{Weed density, dry matter and weed control efficiency}

Weed population and dry weight were significantly reduced due to all weed-control treatments compared with the weedy check. Among the various weed management practices, the lowest weed population and dry weight were recorded under alachlor @ $1.5 \mathrm{~kg}$ a.i $\mathrm{ha}^{-1}$ with one hand weeding on 30 DAS $\left(T_{2}\right)$ (Table 2). This indicated that sequential application of herbicides has reduced the weed density compared to the application of pre-emergence herbicides alone. Hand weeding twice on 15 and 30 DAS $\left(T_{10}\right)$ is at a par with $\mathrm{T}_{2}$ treatment (Table 2). Lower weed dry matter was noticed at all the stages of crop growth. Removal of weeds that germinated along with crop during the first hand weeding and removal of weeds that germinated afterwards during the second hand weeding and smothering of weeds by crop thereafter could be attributed to this. Invariably unweeded control $\left(\mathrm{T}_{12}\right)$ registered highest total weed population and dry weight with maximum grass, sedge and broad leaved weed populations (Table 2). The current results are in conformity with the findings of Pandey et al., (2000), Maliya and Singh (2007).

Weed-control efficiency (WCE) of different treatments varied from $63.55-90.33 \%$. Among all the treatments, alachlor @ $1.5 \mathrm{~kg}$ a.i ha ${ }^{-1}$ with one hand weeding on 30 DAS $\left(T_{2}\right)$ was the most effective in controlling the weeds (WCE 90.33\%), followed by hand weeding twice on 15 and 30 DAS( $\mathrm{T}_{10}$ )(WCE 84.08\%) (Table 2). This could be attributed to the weed free condition achieved during the critical period of crop growth with two hand weeding. Weed control efficiency recorded with pre-emergence application of atrazine with one hand weeding was high at all the stages of crop growth. This could be due to the fact that the initial weed population was effectively controlled by persistence activity of pre-emergence application of atrazine. The results are in line with the findings of Malviya et al., (2012), Mundra et al., (2002), Selvakumar and Sundari (2006) and Kamble et al., (2005).

\section{References}

Kamble, T.C., S.U. Kakade, S.U. Nemade, R.V. Pawar and V.A. Apotikar. 2005. 
Integrated weed management in maize. Crop Res., 29(3): 396-400.

Malviya, A. and B. Singh. 2007. Weed dynamics, productivity and economics of maize (Zea mays) as affected by integrated weed management under rainfed conditions. Indian J. Agron., 52(4): 321-324.

Malviya, A., N. Malviya, B. Singh and A.K. Singh. 2012. Integrated weed management in maize (Zea mays) under rainfed conditions. Indian J. Dryland Agric. Res. Development, 27(1): 70-73.

Mundra, S.L., A.K. Vyas and P.L. Mailwal. 2002. Effect of weed and nutrient management on nutrient uptake by maize and weeds. Indian J. Agron., 43(3): 378-383.

Pandey, A.K., V. Prakash, R.D. Singh and V.P. Mani. 2000. Effect of herbicides mixtures and cultural practices on maize and associated weeds under mid hills of N-W Himalayas. Annals of Agric. Res., 21(1): 58-64.

Pandey, A.K., V. Prakash, R.D. Singh, R.D and V.P. Mani. 2001. Integrated Weed
Management in maize (Zea mays). Indian J. Agron., 46(2): 260-265.

Sakthivel, N., M. Revathi and S. Bhuvana Devi. 2014. Effect of the tillage and weed management in maize and sunflower cropping system. Biennial Conference of Indian Soc. Weed Sci., pp.200.

Sandhya Rani, B and G. Karuna Sagar. 2013. Effect of integrated weed management on growth, yield and economics of sweet corn. Agric. Sci. Digest, 33(1): $52-55$.

Selvakumar, T and A. Sundari. 2006. Effect of intercropping systems and weed management practices on weeds in maize (Zea mays). Indian J. Weed Sci., 38(1\&2): 133-134.

Sunitha, N., P. Maheswara Reddy and D.S. Reddy. 2011. Influence of planting pattern and weed control practices on weed growth, nutritive uptake and productivity of sweet corn. Crop Research. 41 (1, 2 \& 3): 13-20.

\section{How to cite this article:}

Nagasai Vardhan Naik, R. and Velayutham, A. 2018. Weed Dynamics and Productivity of Hybrid Maize (Zea mays) as Affected by Integrated Weed Management Practices. Int.J.Curr.Microbiol.App.Sci. 7(03): 2984-2989. doi: https://doi.org/10.20546/ijcmas.2018.703.345 